\title{
Impact of insomnia on self-perceived health in the elderly
}

\author{
O impacto da insônia na auto-percepção de saúde do idoso \\ Janiciene Silva ${ }^{1}$, Annibal Truzzi', Fayanne Schaustz', Roberta Barros², Marisa Santos ${ }^{3}$, Jerson Laks ${ }^{1,4}$
}

\begin{abstract}
Health self-perception is a strong indicator of the health of a population. Objective: To investigate the association between self-perceived health, and sociodemographic and clinical factors in a sample of elderly outpatients in Rio de Janeiro. Methods: A sample of 345 elderly patients was assessed with an anamnesis, Lawton and Brody's Scale, Katz Index, Geriatric Depression Scale, Timed Up and Go Test, and Study of Osteoporotic Fracture Index. Logistic regression analyses were performed to investigate the predictors of self-perceived health. Results: Risk of falls, frailty, functional performance on the Instrumental Activities of Daily Living, insomnia, and familial support were related to self-perceived health. Insomnia was the variable that strongly influenced self-perceived health $(\mathrm{OR}=0.47, \mathrm{Cl} 95 \%: 0.28-0.80$, $p=0.01$ in our sample. Conclusions: The investigation of insomnia in the elderly should be routinely performed in primary care, because of the negative impact it imposes on the health of this population.
\end{abstract}

Keywords: self concept; aged; sleep initiation and maintenance disorders.

\section{RESUMO}

A autopercepção de saúde é um forte indicador de saúde da população. Objetivo: Investigar a associação entre a autopercepção de saúde e os fatores clínicos e sociodemográficos de um grupo de idosos atendidos em um pólo de atenção secundária no Rio de Janeiro. Métodos: A amostra composta por 345 idosos foi avaliada através da anamnese dirigida, Escala de Lawton e Brody, Índice de Katz, Índice de SOF, Escala de Depressão Geriátrica e o Teste Timed Up and Go. Análises de regressão logística foram realizadas para avaliar quais os fatores preditores da autopercepção de saúde. Resultados: 0 risco de quedas, a fragilidade, a performance nas Atividades Instrumentais de Vida Diárias, a insônia e o suporte familiar foram as variáveis relacionadas à autopercepção de saúde. A insônia foi a variável que mais influenciou na autopercepção de saúde na nossa amostra. (OR = 0,47, IC95\%: 0,28-0,80, p = 0,01). Conclusões: A investigação de insônia no idoso deve ser realizada rotineiramente na atenção primária, devido ao impacto negativo que ela exerce na saúde desta população.

Palavras-chave: autoimagem; idoso; distúrbios do início e da manutenção do sono.

Self-perceived health (SPH) can be defined as a global health evaluation performed by subjective self-judgement. It is considered an integrated indicator of health, which is associated with social, psychological and biological aspects of the individual. Furthermore, it is recommended by the World Health Organization as a strong indicator of health and life expectancy of the population ${ }^{1,2}$.

Self-perceived health has been broadly investigated in gerontological research through the formulation of a simple question "In general, how do you rate your health?". Despite the fact that it is a simple and direct question, it provides similar results to objective health evaluations, and has been documented as a strong predictor of functional decline, morbidity and mortality, social well-being, better recovery of illness and quality of life $\mathrm{e}^{1,2,3,4}$.

In the elderly, SPH is influenced by multiple factors such as gender, familial and social support, marital status, scholarship, social and economic status, chronic conditions, lifestyle and functionality ${ }^{2,45,5,7}$. According to Hartmann ${ }^{2}$, a higher level of scholarship and income are related to better SPH. Poor SPH in the elderly is associated with the presence of chronic diseases and high levels of dependence ${ }^{2}$. The study conducted by Carvalho et al. ${ }^{4}$ found that SPH correlated with the following variables: gender, chronic diseases, low scholarship, absence of occupation, and reduced physical activity. Silva and Menezes ${ }^{5}$ identified that women rated

\footnotetext{
1Secretaria Estadual de Saúde do Rio de Janeiro, Instituto Vital Brasil, Centro de Estudo e Pesquisa do Envelhecimento, Rio de Janeiro RJ, Brasil; IInstituto Nacional do Câncer (INCA), Rio de Janeiro RJ, Brasil; 
their health worse than men, and that income was a strong predictor of SPH in the elderly. Angina, stroke and chronic pulmonary disease were the conditions that remained associated with SPH in the study. The authors also found a strong relationship between pain and functionality, and $\mathrm{SPH}^{5}$. Chronic diseases, income, gender, and functional ability were also associated with SPH in the elderly, in two studies conducted in Brazil ${ }^{6,7}$.

The identification of the factors that influence SPH in the elderly who are assisted in primary care may help in the development of better public health strategies as, for example, the improvement of patient adherence to health services and treatments, as well as acting positively in the promotion of a healthy lifestyle. We hypothesize that elders with low socioeconomic status and a higher level of functional impairment will rate their $\mathrm{SPH}$ worse. We aimed to investigate the association between SPH and clinical and sociodemographic factors of elderly outpatients who were evaluated at a secondary care unit.

\section{METHODS}

\section{Sample}

Three hundred and forty-five elders were consecutively evaluated in the period between April 2012 and May 2013 in a secondary care unit that performs multidisciplinary geriatric and gerontological assessment of outpatients who are at least 60 years old and are recruited from primary care units.

The majority of the sample comprised women, in their sixties, with low socioeconomic status, and with adequate familial and social support. Sociodemographic characteristics of the sample are described in Table 1.

We excluded those who had a diagnosis of dementia $(n=19)$ and who did not answer the question regarding SPH. The final sample consisted of 326 elders.

\section{Instruments}

Sociodemographic (gender, age, marital status, scholarship, familial, and social support) and clinical characteristics (insomnia and comorbidities) were assessed through direct anamnesis and clinical examination. Insomnia was defined according to ICD-10 criteria $^{8}$.

Self-perceived health was assessed though direct interview with the question: "In general, how do you rate your health?" The elder could rate their SPH among five possible answers: very good, good, reasonable, bad and very bad. A similar evaluation of SPH was performed in the study conducted by Jardim et al. ${ }^{9}$

The ability to perform instrumental activities of daily living (IADL) and activities of daily living (ADL) were assessed through Lawton and Brody's Instrumental Activities of Daily Living Scale ${ }^{10}$ and the Katz Index ${ }^{11}$, respectively.

The IADL scale evaluates the ability to perform instrumental tasks, such as going out alone, performing small household repairs, managing medication, making phone calls and taking care of finances. The scale consists of nine items, which are graded between 0 (normal) and 3 (disabled). The final score is obtained through the sum of each item's score. The maximum score is 27 (severely disabled) ${ }^{10}$.

The Katz Index assesses the person's ability to perform basic activities of daily living such as bathing, dressing, and eating. The scale has six items and the final result indicates independence, or total or partial dependence to perform $\mathrm{ADL}^{11}$.

Frailty was evaluated through the Study of Osteoporotic Fracture Index ${ }^{12}$, which is an instrument that assesses frailty in the elderly according to three parameters: loss of $5 \%$ of weight, the ability to stand up without holding the armchair, and feeling full of energy. Each question is answered "Yes" or "No", and two "Yes" answers to the first two questions and/or a "No" to the third are required to classify the person as frail.

Depression was assessed through the Geriatric Depression Scale $-5^{13}$ which evaluates the risk for depression in the elderly, and comprises five questions with a Yes/No answer.

The Timed Up and Go Test was used to evaluate the risk of falls. It consists of a quick test, in which the person is asked to stand up, walk approximately $2.44 \mathrm{~m}$, go back and sit down again, as fast as possible. If the person executes this task in a timeframe less than 10 seconds, it corresponds to an absence of risk. A timeframe between 10 and 20 seconds corresponds to a moderate risk of falls, and greater than 20 seconds to high risk of falls ${ }^{14}$.

Visual acuity was evaluated through Snellen's scale ${ }^{15}$.

Socioeconomic status was obtained using the ABIPEME Criteria of Brazilian Socioeconomic Classification ${ }^{16}$.

Table 1. Sociodemographic data $(n=326)$.

\begin{tabular}{|c|c|c|}
\hline Variable & $n$ & $\%$ \\
\hline \multicolumn{3}{|l|}{ Gender } \\
\hline Female & 216 & 66.3 \\
\hline Male & 110 & 33.7 \\
\hline \multicolumn{3}{|l|}{ Age (years) } \\
\hline $60-69$ & 137 & 42.0 \\
\hline $70-79$ & 125 & 38.3 \\
\hline$\geq 80$ & 64 & 19.6 \\
\hline \multicolumn{3}{|l|}{ Marital status } \\
\hline Married & 108 & 33.1 \\
\hline Single/ Divorced & 119 & 36.5 \\
\hline Widow & 99 & 30.4 \\
\hline \multicolumn{3}{|l|}{ Scholarship (year) } \\
\hline$<1$ & 137 & 42.0 \\
\hline $1-8$ & 142 & 43.6 \\
\hline$>8$ & 47 & 14.4 \\
\hline \multicolumn{3}{|l|}{ Socioeconic status } \\
\hline$A$ & 0 & $0 \%$ \\
\hline B & 1 & 1.2 \\
\hline C & 61 & 18.7 \\
\hline$D$ & 197 & 60.4 \\
\hline E & 64 & 19.6 \\
\hline \multicolumn{3}{|l|}{ Social support } \\
\hline Adequate & 303 & 92.9 \\
\hline Inadequate & 23 & 7.1 \\
\hline \multicolumn{3}{|l|}{ Familial support } \\
\hline Adequate & 302 & 92.6 \\
\hline Inadequate & 24 & 7.4 \\
\hline
\end{tabular}




\section{Statistical analysis}

Sociodemographic data analyses were performed through means and standard deviations or percentages. The Chi Squared test was used to compare sociodemographic and clinical variables. The SPH was dichotomized into good or bad. Age was categorized into three groups: 60- 69 years old, 70-79 years old, and $\geq 80$ years old.

We dichotomized the SPH into good (very good, good, reasonable) and bad (bad, very bad).

The risk of falls was dichotomized into with, and without, risk. We also dichotomized the ability to perform ADL and IADL into dependent or independent.

In order to identify the predictors of SPH, we performed logistic regression analyses with SPH as the dependent variable. Variables that were associated with SPH in binomial analyses were included as explanatory variables. Results were considered statistically significant if the $p$-value was $\leq 0.05$.

\section{Ethical aspects}

The project entitled "Polo de Atenção Secundária" of the Centre for Research and Studies on Ageing (CEPE) was approved by the Ethics Committee in Research.

Table 2. Health self-perception according to sociodemographic characteristics.

\begin{tabular}{|c|c|c|c|c|c|}
\hline \multirow{2}{*}{ Variable } & \multicolumn{2}{|c|}{ SPH good } & \multicolumn{2}{|c|}{ SPH bad } & \multirow{2}{*}{$\mathrm{p}^{*}$} \\
\hline & $\mathrm{n}$ & $\%$ & $n$ & $\%$ & \\
\hline \multicolumn{6}{|l|}{ Gender } \\
\hline Female & 74 & 22.7 & 142 & 43.6 & \multirow[t]{2}{*}{0.10} \\
\hline Male & 48 & 14.7 & 62 & 19.0 & \\
\hline \multicolumn{6}{|l|}{ Age (years) } \\
\hline $60-69$ & 46 & 14.1 & 91 & 27.9 & \multirow{3}{*}{0.44} \\
\hline $70-79$ & 49 & 15.0 & 76 & 23.3 & \\
\hline$\geq 80$ & 27 & 8.3 & 37 & 11.3 & \\
\hline \multicolumn{6}{|l|}{ Marital status } \\
\hline Married & 39 & 12.0 & 69 & 21.1 & \multirow{3}{*}{0.88} \\
\hline Single/ Divorced & 44 & 13.5 & 75 & 23. & \\
\hline Widowed & 39 & 12.0 & 60 & 18.4 & \\
\hline \multicolumn{6}{|l|}{ Scholarship (year) } \\
\hline$<1$ & 51 & 15.6 & 75 & 26.4 & \multirow{3}{*}{0.51} \\
\hline $1-8$ & 50 & 15.3 & 92 & 28.2 & \\
\hline$>8$ & 21 & 6.4 & 26 & 7.9 & \\
\hline \multicolumn{6}{|l|}{ Socioeconimic status } \\
\hline A & 0 & 0 & 0 & 0 & \multirow{5}{*}{0.24} \\
\hline $\mathrm{B}$ & 3 & 0.9 & 1 & 0.3 & \\
\hline C & 23 & 7.1 & 38 & 11.6 & \\
\hline D & 78 & 23.9 & 88 & 36.5 & \\
\hline$E$ & 18 & 5.5 & 46 & 14.1 & \\
\hline \multicolumn{6}{|l|}{ Social support } \\
\hline Adequate & 116 & 35.6 & 187 & 57.4 & \multirow[t]{2}{*}{0.24} \\
\hline Inadequate & 6 & 1.8 & 17 & 5.2 & \\
\hline \multicolumn{6}{|l|}{ Familial support } \\
\hline Adequate & 117 & 35.9 & 185 & 56.8 & \multirow[t]{2}{*}{0.08} \\
\hline Inadequate & 5 & 1.5 & 19 & 5.9 & \\
\hline
\end{tabular}

SPH: Self-perceived health; y: years; * : Chi-squared test.

\section{RESULTS}

More than half of our patients referred their SPH as bad $(\mathrm{n}=204 ; 63 \%)$. Hypertension $(\mathrm{n}=279 ; 86 \%)$, insomnia ( $\mathrm{n}=125 ; 38 \%)$, and low visual acuity $(\mathrm{n}=103 ; 33 \%)$ were the most common comorbidities. Most of our patient group comprised elders who independently perform their IADL ( $\mathrm{n}=239 ; 73 \%)$ and basic ADL ( $\mathrm{n}=293 ; 90 \%)$.

Elders with inadequate familial support showed a tendency to refer to their SPH as bad $(p=0.08)$. However, better SPH was reported by those who were functionally able to perform IADL independently $(p=0.01)$, with no risk of falls $(p<0.05)$, non-frail $(\mathrm{p}<0.05)$, and without insomnia $(\mathrm{p}<0.01)$ (Tables 2 and 3$)$.

We carried out logistic regression analyses with SPH as a dependent variable, and functional ability to perform IADL, risk of falls, frailty, insomnia, and familial support as explanatory variables. Insomnia (OR= 0.47, CI 95\%: $0.2-0.80, p=0.01$ ) was the only variable that was significantly associated with SPH (Table 4).

Table 3. Self-perceived health according to clinical and functional characteristics.

\begin{tabular}{|c|c|c|c|c|c|}
\hline \multirow{2}{*}{ Variable } & \multicolumn{2}{|c|}{ SPH good } & \multicolumn{2}{|c|}{ SPH bad } & \multirow{2}{*}{$\mathrm{p}^{\mathrm{a}}$} \\
\hline & $n$ & $\%$ & $n$ & $\%$ & \\
\hline \multicolumn{6}{|l|}{ Hypertension } \\
\hline Yes & 105 & 32.2 & 174 & 53.4 & 0.85 \\
\hline No & 17 & 5.2 & 30 & 9.2 & \\
\hline \multicolumn{6}{|l|}{ Diabetes } \\
\hline Yes & 34 & 10.4 & 63 & 19.3 & 0.57 \\
\hline No & 88 & 27.0 & 141 & 43.2 & \\
\hline \multicolumn{6}{|l|}{ Osteoarthritis } \\
\hline Yes & 29 & 8.9 & 64 & 19.6 & 0.14 \\
\hline No & 93 & 28.5 & 140 & 42.9 & \\
\hline \multicolumn{6}{|l|}{ Stroke } \\
\hline Yes & 7 & 2.1 & 15 & 4.6 & 0.57 \\
\hline No & 115 & 35.3 & 189 & $-58 \%$ & \\
\hline \multicolumn{6}{|l|}{ Depression } \\
\hline Yes & 25 & 7.7 & 50 & 15.3 & 0.40 \\
\hline No & 97 & 29.8 & 154 & 47.2 & \\
\hline \multicolumn{6}{|l|}{ Vision* } \\
\hline Normal & 80 & 25.6 & 130 & 41.5 & 0.84 \\
\hline Impaired & 38 & 12.1 & 65 & 20.8 & \\
\hline \multicolumn{6}{|l|}{ Risk of falls** } \\
\hline Without risk & 98 & 32.1 & 141 & 46.3 & 0.02 \\
\hline With risk & 17 & 5.6 & 49 & 16.1 & \\
\hline \multicolumn{6}{|l|}{ Frailty } \\
\hline Non frail & 110 & 33.7 & 164 & 50.3 & 0.02 \\
\hline Frail & 12 & 3.7 & 40 & 12.3 & \\
\hline \multicolumn{6}{|l|}{ Sleep disorder } \\
\hline Yes & 32 & 9.8 & 93 & 28.6 & $<0.01$ \\
\hline No & 90 & 27.6 & 111 & 34.1 & \\
\hline \multicolumn{6}{|l|}{ IADL } \\
\hline Independent & 99 & 30.4 & 140 & 42.9 & 0.01 \\
\hline Dependent & 23 & 7.1 & 64 & 19.6 & \\
\hline \multicolumn{6}{|l|}{$A D L$} \\
\hline Independent & 112 & 34.4 & 181 & 55.5 & 0.37 \\
\hline Dependent & 10 & 3.1 & 23 & -7 & \\
\hline
\end{tabular}

SPH: Self-perceived health; ${ }^{\text {: }}$ Chi-Squared Test; ${ }^{*} n=313 ;{ }^{* *} n=305 ; \mid \mathrm{ADL}$ : Instrumental activities of daily living; ADL: Activities of daily living. 
Table 4. Logistic regression analyses predicting self-perceived health.

\begin{tabular}{lccccccc} 
Variable & $\mathrm{B}$ & $\mathrm{EP}$ & Wald & $\mathrm{df}$ & $\mathrm{p}$ & OR & $95 \% \mathrm{Cl}$ for OR \\
\hline IADL & 0.45 & 0.30 & 2.26 & 1 & 0.13 & 1.56 & $0.87-2.80$ \\
\hline Insomnia & -0.75 & 0.27 & 7.93 & 1 & 0.01 & 0.47 & $0.28-0.80$ \\
Frailty & 0.45 & 0.39 & 1.32 & 1 & 0.25 & 1.56 & $0.73-3.35$ \\
Risk of falls & 0.46 & 0.33 & 1.93 & 1 & 0.16 & 1.58 & $0.83-3.00$ \\
Familial support & 0.78 & 0.59 & 1.72 & 1 & 0.19 & 2.17 & $0.68-6.90$ \\
Constant & 0.69 & 0.25 & 7.89 & 1 & 0.01 & 2.00 & \\
\hline
\end{tabular}

IADL: Instrumental activities of daily living; OR: Odds Ratio; Cl: Confidence Interval; B: Beta coefficient; EP:Epsilon; df: degrees of freedom; p: p-value.

\section{DISCUSSION}

This study showed that elders who depended on others to perform IADL, were frail, with risk of falls, and had insomnia, had a worse SPH. Insomnia was the strongest predictor of a poor SPH in our patients.

This finding is consistent with other studies that found a significant association between functional ability and $\mathrm{SPH}^{2,5,7,17,18}$.

A study conducted in Brazil with 363 elders, found that those who reported not being able to count on anyone if they were to become bedridden reported worse SPH. According to the authors, feelings of insecurity of not having anyone to count on, contributed to a worse $\mathrm{SPH}^{17}$. In Brazil, it is estimated that approximately $90 \%$ of the elders who need some care depend on their families ${ }^{19}$. This evidence may partly explain our findings, as we found that those with adequate familial support showed a tendency to evaluate their health positively.

We found that elders who were not frail showed a better SPH. The study conducted by Moreira and Lourenço ${ }^{20}$ with 847 elders, found a strong association between SPH and frailty. Thomaz and Fattori ${ }^{21}$ also found a significant relationship between poor SPH and frailty.

According to the literature, history and fear of falls help to promote a poor quality of life and contribute to the institutionalization of the elderly ${ }^{22}$. In our study, those with a risk of falls showed worse SPH.

A Brazilian study conducted by Vagetti et al. ${ }^{23}$ found that a significant proportion of female elders who lived in low-income regions referred to their SPH negatively. The authors found that eight out of 10 female elders evaluated their health as bad or very bad. Physical, psychological and environmental aspects showed strong associations with SPH. Feelings of insecurity of physical integrity, and scarce financial and leisure resources, were significant predictors of a negative $\mathrm{SPH}^{23}$.

This study found that insomnia was the factor that exerted the greatest impact on SPH in our patients. Our results are consistent with those of Magee et al. ${ }^{24}$ who found a strong relationship between bad SPH and short sleep duration. The prevalence of sleep disorders increases with age ${ }^{25,26}$. A study that included more than 16,000 elders from developing countries found that the prevalence of sleep disorders ranged from $9.1 \%$ to $37.7 \%{ }^{27}$.

Contrary to our hypotheses, neither sociodemographic status nor functional impairment significantly predicted SPH. The review conducted by Pagotto et al. ${ }^{28}$ suggests that $\mathrm{SPH}$ in the elderly is influenced by socioeconomic status, as elders with low socioeconomic status have less access to medical services and show low adherence to medical treatments. Also, according to the authors, SPH is more affected by functional impairment to perform ADL than suffering from a chronic disease.

Our study has some limitations that should be considered. The cross-sectional design of the study does not allow us to make any causal inferences regarding the identified associations. Longitudinal studies are necessary to further investigate the relationship between insomnia and $\mathrm{SPH}$ among elders derived from low-income primary care units.

To sum up, SPH was strongly correlated with insomnia in our study. The investigation of insomnia in the elderly should be routinely performed in primary care because of the negative impact it imposes on the health of this population.

\section{References}

1. Valente LE. Autopercepção de saúde de cuidadores familiares de pacientes com demência [dissertation]. Rio de Janeiro: Universidade Federal do Rio de Janeiro; 2013.

2. Hartmann ACVC. Fatores associados à autopercepção de saúde em idosos de porto alegre [thesis]. Porto Alegre: Pontifícia Universidade Católica do Rio Grande do Sul; 2008.

3. Agostinho MR, Oliveira MC, Pinto MEB, Balardin GU, Harzheim E. Autopercepção da saúde entre usuários da Atenção Primária em Porto Alegre, RS. R Bras Med Fam Comun. 2010;5(17):9-15. http://doi.org/10.5712/rbmfc5(17)175
4. Carvalho FF, Santos JN, Souza LM, Souza NRM. [Analysis of perception of the health status of elderly from the metropolitan area of Belo Horizonte city]. Rev Bras Geriat Gerontol. 2012;15(2):285-93. Portuguese. http://doi.org/10.1590/S1809-98232012000200011

5. Silva TR, Menezes PR. Autopercepção de saúde: um estudo com idosos de baixa renda de São Paulo. Rev Med. 2007;86(1):28-38. http://doi.org/10.11606/issn.1679-9836.v86i1p28-38

6. Rocha SV, Freire MO. [Habitual physical activity level and self-perception of health status in aged women of Jequié-Bahia]. Rev Bras Prom Saúde. 2007;20(3):161-7. Portuguese. 
7. Alves LS, Rodrigues RN. [Determinants of self-rated health among elderly persons in São Paulo, Brazil]. Rev Panam Salud Publica. 2005;17(5/6):333-41. Portuguese. http://dx.doi.org/10.1590/S1020-49892005000500005

8. World Health Organization - WHO. The ICD-10 Classification of mental and behavioural disorders: clinical descriptions and diagnostic guidelines. Geneva: World Health Organization;1992.

9. Jardim R, Barreto SM, Giatti L. Self-reporting and secondary informant reporting in health assessments among elderly people. Rev Saúde Pública. 2010;44(6):1120-9. http://doi.org/10.1590/S0034-89102010000600018

10. Santos RL, Virtuoso Júnior JS. [Reliability of the Brazilian version of the Scale of Instrumental Activities of Daily Living]. Rev Bras Prom Saúde. 2008;21(4):290-6. Portuguese.

11. Lino VTS, Pereira SRM, Camacho LAB, Ribeiro Filho ST, Buksman S. [Cross-cultural adaptation of the Independence in Activities of Daily Living Index (Katz Index)]. Cad Saúde Pública. 2008;24(1):103-12. Portuguese. http://doi.org/10.1590/S0102-311X2008000100010

12. Fried LP, Tangen CM, Walston J, Newman AB, Hirsch C, Gottdiener J T et al. Frailty in older adults: evidence for a phenotype. J Gerontol A Biol Sci Med Sci. 2001;56(3):M146-57. https://doi.org/10.1093/gerona/56.3.M146

13. Hoyl MT, Alessi CA, Harker JO, Josephson KR, Pietruska FM, Koelfgen M et al. Development and testing of a five item version of the Geriatric Depression Scale. J Am Geriatr Soc. 1999;47(7):873-8. https://doi.org/10.1111/j.1532-5415.1999.tb03848.x

14. Cabral ALL. Tradução e validação do teste Timed Up and Go e a sua correlação com diferentes alturas da cadeira [dissertation]. Brasília, DF: Universidade Católica de Brasília; 2011.

15. Brunner LS, Suddarth DS. Tratado de enfermagem médico-cirúrgica. Rio de Janeiro: Guanabara Koogan; 1998.

16. Associação Brasileira de Empresas de Pesquisa - ABEP. Critério de classificação econômica Brasil 2012. São Paulo: ABEP; 2013 [cited 2015 Jan 28]. Available from: http://www.abep.org/novo/ Content.aspx?ContentID=301

17. Nunes APN, Barreto SM, Gonçalves LG. [Social relations and self-rated health: the ageing and health project] Rev Bras Epidemiol. 2012;12(2):415-28. Portuguese. http://doi.org/10.1590/S1415-790×2012000200019
18. Lee Y, Shinkai S. A comparison of correlates of self-rated health and functional disability of older persons in the Far East: Japan and Korea. Arch Gerontol Geriatr. 2003;37(1):63-76.

19. Freitas EV, Py L. Tratado de geriatria e gerontologia. 3a ed. Rio de Janeiro: Guanabara Koogan; 2011.

20. Moreira VG, Lourenço RA. Prevalence and factors associated with frailty in an older population from the city of Rio de Janeiro, Brazil: the FIBRA-RJ Study. Clinics. 2013;68(7):979-85. http://doi.org/10.6061/clinics/2013(07)15

21. Thomaz RP, Fattori A. Auto-percepção de saúde, auto-avaliação da acuidade visual e síndrome da fragilidade em idosos de um hospital terciário - HC/UNICAMP. In: 19. Congresso Interno de Iniciação Científica. Faculdade de Ciências Médicas - FCM, UNICAMP; 2011 [cited 2015 Jan 28]. Available from: http://www.prp.rei.unicamp. br/pibic/congressos/xixcongresso/paineis/063993.pdf

22. Delbaere K, Close JCT, Brodaty H, Sachdev P, Lord ST. Determinants of disparities between perceived and physiological risk of falling among elderly people: cohort study. BMJ. 2010;341:c4165. https://doi.org/10.1136/bmj.c4165

23. Vagetti GC, Barbosa Filho VC, Moreira NB, Oliveira V, Mazzardo O, Campos W. [Health conditions and sociodemographic variables associated with quality of life in elderly women from a physical activity program in Curitiba, Paraná State, Southern Brazil]. Cad Saúde Pública. 2013;29(5):955-69. Portuguese. http://doi.org/10.1590/S0102-311X2013000500013

24. Magee CA, Caputi P, Iverson DC. Relationships between self-rated health, quality of life and sleep duration in middle aged and elderly Australians. Sleep Med. 2011;12:346-50. http://doi.org/10.1016/j.sleep.2010.09.013

25. Roepke SK, Ancoli-Israel S. Sleep disorders in the elderly. Indian J Med Res. 2010;131:302-10.

26. Crowley K. Sleep and sleep disorders in older adults. Neuropsychol Rev. 2011;21(1):41-53. http://doi.org/10.1007/s11065-010-9154-6

27. Mazzotti DR et al. Prevalence and correlates for sleep complaints in older adults in low and middle income countries: a 10/66 Dementia Research Group study. Sleep Medicine. 2012;13(6):697-702. http://doi.org/10.1016/j.sleep.2012.02.009

28. Pagotto V, Bachion MM, Silveira EA. [Self-assessment of health by older Brazilians: systematic review of the literature]. Rev Panam Salud Publica. 2013;33(4):302-10. Portuguese. http://doi.org/10.1590/S1020-49892013000400010 